\title{
Scheduling peach orchard irrigation in water stress conditions: use of relative transpiration and predawn leaf water potential
}

\author{
Teresa Afonso do PAço ${ }^{1 *}$, Maria Isabel FerReira ${ }^{1}$, Carlos Arruda PACHeCo ${ }^{2}$
}

${ }^{1}$ CEER - Biosyst. Eng., DCEB Inst. Sup. Agron., Univ. Técn. Lisboa, Tapada da Ajuda, 1349-017 Lisbon, Portugal, tapaco@isa.utl.pt

2 Inst. Sup. Agron., Univ. Técn. Lisboa, Tapada da Ajuda, 1349017 Lisbon, Portugal

${ }^{*}$ Correspondence and reprints

Received 25 June 2012 Accepted 28 September 2012

Fruits, 2013, vol. 68, p. 147-158 (C) 2013 Cirad/EDP Sciences All rights reserved DOI: $10.1051 /$ fruits/2013061 Www.fruits-journal.org

RESUMEN ESPAÑOL, p. 158
Scheduling peach orchard irrigation in water stress conditions: use of relative transpiration and predawn leaf water potential.

Abstract - Introduction. Plant water stress indicators have become valuable for moving towards deficit irrigation strategies and saving water. In this case evapotranspiration (ET) is below its maximum value for the crop and stage (ETc), and a stress coefficient $(K s)$ is applied to obtain actual $E T(E T a)$. Predawn leaf water potential $(\Psi p)$ can be related to relative transpiration $(R T)$, the ratio between transpiration of a stressed plot $(T)$ and transpiration of a well-irrigated plot $(T m)$. Estimating $R T$ from $\Psi p$ allows calculating ETa for determination of irrigation amounts, if deficit irrigation practices are used, as $R T$ corresponds approximately to $K s$. Materials and methods. $R T$ and $\Psi p$ were measured with the aim of establishing a relationship to estimate $R T$ under moderate water stress for irrigation scheduling, in a peach orchard in south Portugal. $R T$ was calculated using sap flow measurements (heat balance method) in two plots, one well-irrigated (daily drip irrigation amounts calculated for $\mathrm{Tm}$ ) and another temporarily without irrigation. Results and discussion. A high correlation was found between $R T$ and $\Psi p$, allowing the estimation of $R T$ for the studied conditions. Significant differences regarding the relationship $R T-\Psi p$ obtained for another peach orchard in the same region and similar soil conditions were found for $\Psi p$ in the range between -0.11 and $-0.45 \mathrm{MPa}$. The results suggest that the differences resulted from the different irrigation systems: drip and micro-sprinkling, as they determine different temporal and spatial water distribution and therefore different geometry of root systems. A formerly proposed equation to estimate $R T$ from $\Psi p$ with a general form for different fruit tree species was tested, proving to be adequate within some limits: when $R T$ is lowered to 0.7 , the error was below $9 \%$. The threshold value $R T=0.7$ was considered a minimum as it was successfully tested in deficit irrigation practices for peach orchards. Portugal / Prunus persica / water stress / soil water deficit / indicators / deciduous plants / fruit trees / water requirements / demand irrigation

Planification de l'irrigation d'un verger de pêchers en conditions de stress hydrique : utilisation de la transpiration relative et du potentiel hydrique foliaire de base.

Résumé - Introduction. Les indicateurs du stress hydrique végétal sont devenus précieux pour conduire des stratégies d'irrigation en cas de déficit et économiser l'eau. Dans ce cas, l'évapotranspiration $(E T)$ est inférieure à sa valeur maximale pour la culture et pour le stade (ETc), et un coefficient de contrainte $(K S)$ s'applique pour obtenir la valeur réelle de $E T(E T r)$. Le potentiel hydrique foliaire de base $(\Psi p)$ peut être lié à la transpiration relative $(R T)$, rapport entre la transpiration d'une parcelle stressée $(T)$ et la transpiration d'une parcelle bien irriguée $(\mathrm{Tm})$. L'estimation de $R T$ à partir de $\Psi p$ permet de calculer l'ETr pour déterminer les doses d'irrigation, si une irrigation en conditions de déficit est appliquée, puisque $R T$ correspond approximativement à $K s$. Matériel et méthodes. $R T$ et $\Psi p$ ont été mesurés afin d'établir une relation pour estimer $R T$ sous un stress hydrique modéré pour programmer l'irrigation dans un verger de pêchers dans le sud du Portugal. $R T$ a été calculé à partir de la mesure du flux de sève (bilan thermique) dans deux parcelles, l'une bien irriguée (quantités d'irrigation journalière au goutte-à-goutte calculées pour $\mathrm{Tm}$ ) et une autre temporairement non irriguée. Résultats et discussion. Une forte corrélation a été observée entre $R T$ et $\Psi p$, ce qui a permis d'estimer $R T$ dans les conditions étudiées. Des différences importantes concernant la relation $R T$ - $\Psi p$ obtenue pour un autre verger de pêchers de la même région, disposant de conditions pédologiques similaires, ont été trouvées pour $\Psi p$ compris entre -0,11 MPa et -0,45 MPa. Les résultats suggèrent que ces différences ont résulté des différents systèmes d'irrigation utilisés : goutte-à-goutte ou microasperseurs, puisque ceux-ci déterminent la distribution spatiale et temporelle de l'eau dans le sol et donc la géométrie différente du système racinaire. Une équation précédemment proposée pour estimer $R T$ à partir $\Psi p$, avec une forme générale pour les différentes espèces d'arbres fruitiers, a été testée et s'avère suffisante dans certaines limites : jusqu'à $R T=0,7$, l'erreur s'est révélée inférieure à $9 \%$. La valeur de seuil $R T=0,7$ a été considérée comme un minimum, car elle a été testée avec succès lors de l'utilisation d'irrigation en conditions de déficit pour les vergers de pêchers.

Portugal / Prumus persica / stress hydrique / déficit hydrique du sol / indicateur / plante à feuilles caduques / arbre fruitier / besoin en eau / irrigation à la demande 


\section{Introduction}

Most irrigation scheduling techniques, regarding irrigation opportunity, are typically based on indirect approaches and rarely use plant water status directly, as discussed, for example, by Goldhamer [1] and Jones [2]. However, there is an increasing need for maximising water productivity as water is becoming a rare resource, namely in dry areas. Plant water stress indicators are becoming necessary to move towards deficit irrigation strategies [3] without prejudice to yield or quality of the product [4]. Such an approach should be more efficient at saving water if coupled with the use of varieties and rootstock tolerant to drought, as recently shown for citrus [5]. Stress indicator studies have been limited [2, 6-8], given the difficulty of automating some of the measurements, e.g., plant water potential and stomatal conductance, although some advances have been made in relating it to automated measurements [9]. Nevertheless, results show that plant water potential, namely predawn leaf water potential $\left(\Psi_{p}\right)$, is one of the most accurate water stress indicators [10, 11].

In addition, aside from knowing when to irrigate, irrigation requires information on the quantity of water to apply. For the case of deficit irrigation, this implies the use of a stress coefficient $\left(K_{s}\right)$ to quantify the reduction imposed on plant transpiration, whenever the ratio between actual evapotranspiration $\left(E T_{a}\right)$ and crop evapotranspiration $\left(E T_{c}\right)$ is below unity, according to the nomenclature used by Allen et al. [12]. The answer to "when and how much to irrigate" can be obtained if $K_{s}$ is related to $\Psi_{p}$. A possible approximation to $K_{S}$ is the relative transpiration $(R T)$, the ratio between transpiration of a waterstressed plot and transpiration of a wellirrigated plot, ranging from 0 to $1 . R T$ can be calculated using sap flow measurements performed simultaneously in stressed and non-stressed plots. $R T$ is useful in the determination of water consumption while it works as a water stress indicator. As its measurement can be automated, the use of a relationship between $R T$ and $\Psi_{p}$ provides $\Psi_{p}$ estimates from these automated measurements of $R T$. Having $R T$ estimated from $\Psi_{p}$ allows calculating $E T_{a}$ for determination of irrigation amounts with deficit irrigation $\left(E T_{a}<E T_{c}\right) . R T$ threshold values can be regarded as immediate trigger values to start irrigation.

Relating $K_{s}$ and soil water depletion (as the sum of evapotranspiration, ET, since the last irrigation) provides a relationship that allows estimating the quantity of water to apply, as well as the right timing, if a threshold value for $K_{s}$ is defined [13-15]).

As demonstrated under a wide range of conditions, $\Psi p$ is a reliable plant water stress indicator [16-18] and transpiration decrease, associated with stomatal closure, has a close relation to leaf water potential variations [19, 20]. Therefore, associating $\Psi_{p}$ and $R T$ potentially provides an adequate way of assessing irrigation scheduling, based on plant sensing.

For peach trees, Ferreira et al. [21] and Valancogne et al. [22] used $\Psi p$ and $R T$ for the detection of a critical threshold for the onset of irrigation. As $\Psi p$ and $R T$, respectively, approximate soil water potential close to the roots and $K_{s}$, we can assume that this relationship (between $\Psi_{p}$ and $R T$ ) depends on root density, the evapotranspiration rate and soil texture, as is well known to be the case from previous works [23] for the relationship between soil water potential and $K_{s}$. Even if mechanistic models based on the underlying physics of the process (e.g., root water extraction models [24]) could be established, it is difficult to have input data in current working conditions.

Valancogne et al. have discussed the possibility of generalising the relationship between $R T$ and $\Psi p$ for fruit trees via an empirical approach [22]. They have established a general $\Psi p$ versus $R T$ function for a group of four fruit tree species (including peach trees under sprinkler and microsprinkler irrigation), using the mean $\Psi p$ observed, before the cut of irrigation $\left(\Psi p_{\max }\right)$ as a normalisation factor. The possibility of generalisation to a larger group of species or conditions would be useful to produce $R T$ estimates for irrigation scheduling. In a first step, these authors measured $\Psi p$ and $R T$ for plum, 
apple, walnut and peach orchards, having observed a strong correlation between $R T$ and $\Psi p$, although with different regression parameters for each experiment.

They found $\left[R T=a \mathrm{e}^{b \Psi}\right]$, Equation (1), with $\Psi p$ in $\mathrm{MPa}$ and $R T$ between 0 and 1 , to be the best relationship. In a second step, the parameters $a$ and $b$ from Eq. (1) (all species) were related to $\Psi p_{\text {max }}$ as:

$$
\begin{gathered}
{\left[a=-0.62 \Psi p_{\max }+1.13\right],} \\
\text { with } r^{2}=0.43, \text { Equation (2), } \\
{\left[b=3.43 \Psi p_{\max }+2.16\right],} \\
\text { with } r^{2}=0.95, \text { Equation (3). }
\end{gathered}
$$

In Eq. (2), the correlation between parameter $a$ and $\Psi p_{\max }$ was not significant. Therefore, the authors opted to use the mean value of $a$ (equal to 1.28 for the five experiments) instead of Eq. (2). Consequently, Eq. (1) became:

$$
\begin{gathered}
{\left[R T=1.28 \mathrm{e}^{\left(3.43 \Psi p_{\max }+2.16\right) \Psi p}\right]} \\
\text { Equation }(4) .
\end{gathered}
$$

Eq. (4) is a general equation that only requires daily $\Psi p$ and the parameter $\Psi p_{\max }$ to predict daily $R T$.

Regarding the hypothesis described above and proposed by Valancogne et al. [22], the work presented here, in a dripirrigated peach orchard, provides an interesting opportunity to compare two experimental settings under similar conditions - the current work and a previous experiment, referred to as "study MS" - but with different irrigation systems. The first objective was to establish the relationship between $R T$ and $\Psi p$, under drip irrigation conditions. A second objective was to test whether the general equation established for peach orchards under sprinkler and micro-sprinkler irrigation for predicting $R T$ in fruit trees (Eq. (1), [22]) holds for our study. If the equation still holds with the parameters of this study, $R T$ could be estimated from $\Psi p$ measurements using a general equation, discarding the need to measure transpiration.

This study specifically addresses drip irrigation conditions and will evaluate whether or not this model is still valid under drip irrigation. The question arises as the irrigation system could determine different root density and volume, which is a fact of importance in such relationships [25, 26].

\section{Materials and methods}

Our work was conducted in a peach (Prunus persica [L.] Batsch) orchard (lat. $38^{\circ} 42^{\prime} \mathrm{N}$, long. $8^{\circ} 48^{\prime} \mathrm{W}$, elevation near 0 ), East of Lisbon, Portugal. This region is characterised by a temperate climate of Mediterranean type with cool, wet winters and hot, dry summers (Csa, Köppen-Geiger classification). Average annual rainfall is around $600 \mathrm{~mm}$ and mean air temperature around $16{ }^{\circ} \mathrm{C}$. During the experiment (days of year: 191 to 200), mean daily temperature was in the range $22^{\circ} \mathrm{C}$ to $26^{\circ} \mathrm{C}$ (absolute maximum and minimum of $38^{\circ} \mathrm{C}$ and $13{ }^{\circ} \mathrm{C}$ ). Mean daily relative humidity was in the range $55 \%$ to $74 \%$ (absolute minimum and maximum of $23 \%$ and $99 \%$ ).

The peach cultivar was Silver King, a nectarine, grafted on GF 677 rootstock. The orchard area was about 60 ha. Trees were planted in 1996, at $5 \mathrm{~m} \times 2 \mathrm{~m}$ spacing. The sandy soil is a haplic arenosol, according to the FAO [27], with $93 \%$ of sand and a very high infiltration capacity and drainage (saturated hydraulic conductivity higher than $\left.100 \mathrm{~mm} \cdot \mathrm{h}^{-1}\right)$.

Trees were irrigated daily in the evening with a drip system providing about $4 \mathrm{~mm}$ of water. The drippers were located in the row, $0.50 \mathrm{~m}$ away from each tree (2000 emitters per ha). The wetted area at the soil surface was $6.4 \%$ of total area, located near the trees, with drier soil at half distance between trees.

Root distribution was observed with the excavation method and a combination of remote sensing techniques, as described by Hagrey and Michaelsen [28].The envelope of the root branch distribution is nearly oval and measures $0.6 \mathrm{~m}$ to $0.8 \mathrm{~m}$ in diameter [28] until a maximum depth of $0.4 \mathrm{~m}$, with no apparent access to the water table (at $1.6 \mathrm{~m}$ depth) .

Plot A was kept irrigated during the whole period (July 1998), while plot B was 
not irrigated for a period of nine days (days of year: 191 to 199, 9-17 July). This allowed the development of a stress cycle that was terminated when trees were under severe stress, as determined by $\Psi p$ measurements and visual observation.

Ferreira et al. performed successive stress cycles of about 16 days, with a similar peach cultivar (Maybelle) and in similar Haplic Arenosol, within the same class of hydraulic properties (as the one described above) in the same lithological and climatic region [21]. In this case, however, the roots were concentrated at a depth of $0.3 \mathrm{~m}$ to $0.5 \mathrm{~m}$ but were observed up to $1.35 \mathrm{~m}$ (see below), the soil profile being free from rootrestricting features up to $0.9 \mathrm{~m}$ and with no access to the water table (at $2.0 \mathrm{~m}$ depth) [21]. The authors also used a reference wellwatered plot, irrigated every 3-4 days (micro-sprinkler). The decrease in transpiration in the reference plot during these 3-4 days was taken into account. For this, a climatic reference (reference evapotranspiration, $E T_{O}$ ) was used, supposing a constant crop coefficient during this period. These results are referred to elsewhere in this paper (as "study MS" - micro-sprinkler) and were included in Valancogne et al.'s [22] model (Eq. 4).

A Scholander-type pressure chamber was used to measure $\Psi p$ before sunrise on a daily basis from the 190th day of the year to the 205th day of the year (8-23 July, $n=12$ ). The average of the observed $\Psi p$ before the beginning of the drought period $\left(\Psi p_{\max }\right.$ ) was calculated with measurements of the 190th and 191st days of the year.

The relative transpiration, $R T$, was calculated from daily totals of sap flow measurements obtained with the heat balance method [29, 30] adapted from Sakuratani [31]. This method is based on the energy balance equation, applying heat to a certain volume of the trunk, measuring the heat storage and all three conduction terms to calculate the heat convection by difference and relating it to mass convection. Thermocouple probes were inserted in the trunk to evaluate the four terms described above. The heating band was $10 \mathrm{~cm}$ in height and the gauges were $1 \mathrm{~cm}$ in length. The sap flow sensors were placed in the trunk of four trees in the stressed plot (plot B) and in eight trees in the irrigated plot (plot A). Data were logged in CR7 data loggers (Campbell Scientific, UK), with an average each $15 \mathrm{~min}$ and further cumulated to obtain daily totals. For upscaling, we observed that the daily sap flow rate $(S F$, calculated as the mean of the 12 sampled trees, during the period of the 188th to 191st days of the year, when the 12 trees were well irrigated) was well correlated with trunk perimeter, $P\left(S F\left[\mathrm{~L} \cdot \mathrm{d}^{-1}\right]=\right.$ $\left.1.05 \cdot P[\mathrm{~cm}], r^{2}=0.66\right)$. The perimeter of the trunk in sampled trees varied between $9 \mathrm{~cm}$ and $22 \mathrm{~cm}$ and the mean in the plot was $16.74 \mathrm{~cm}$. Daily stand mean transpiration was calculated from daily transpiration of the sampled plants weighted by the trunk perimeter of each tree and normalised by the mean perimeter of the plot, using the methodology detailed in Valancogne et al. [32]. Concerning tree transpiration, variability of the sample was accessed by weighted standard deviation $\left(s d_{w}\right)$, defined as:

$$
s d_{w}=\sqrt{\frac{\sum_{j=1}^{n} w_{j}\left(x_{j}-\overline{x_{w}}\right)^{2}}{\frac{\left(n^{\prime}-1\right) \sum_{j=1}^{n} w_{j}}{n^{\prime}}}}, \text { Equation (5), }
$$

where $n$ is the number of sampled trees, $w_{j}$ are the weights [32], $x_{j}$ the observed values, $\overline{x_{w}}$ the weighted mean of the observations and $n^{\prime}$ the number of non-zero weights (for upscaling, weights are given by the percentage of trees belonging to each class diameter in the stand). Daily transpiration per unit of ground area $\left[\mathrm{mm} \cdot \mathrm{d}^{-1}\right]$ was calculated, taking into account planting density. For each day of the drying cycle, $R T$ was calculated as the ratio between transpiration of the stressed plot and transpiration of the well-irrigated plot. In fact, all four plants provided very similar data. Results were normalised using the last day with well-irrigated conditions (day of year 191, when $R T$ was forced to 1 ), accounting for the possible lack of representativeness of the studied plants. $R T$ was adjusted concomitantly for the following days, using a multiplicative factor. 


\section{Results}

The average transpiration rate, $R T$ and $\Psi p$ primary data and respective standard deviation, measured for the drying cycle analysed, evidenced clear differences between irrigated and stressed plants (figure 1). First, the relationship between $R T$ (normalised data) and $\Psi p$ was established. A $R T-\Psi p$ relationship (during the stress cycle) was found for the situation under study, using a function of the type $\left[R T=a \mathrm{e}^{b \Psi}\right.$ ] (Eq. (1):

$R T=1.60 \mathrm{e}^{2.54 \Psi p}$ (Equation 6) (figure 2a)

In a second step and as described above, the results of our study (daily drip-irrigated peach orchard in a sandy soil) were compared with another previous experiment in the same region, with a similar cultivar and soil ("study MS"), yet with a different irrigation system (micro-sprinkler [21]) and frequency. In that experiment, irrigation took place every 3 or 4 days and the sprinklers were located $4 \mathrm{~m}$ apart along the row and $1 \mathrm{~m}$ away from the nearest tree. The wetted area after irrigation was $12 \%$ of the total area (in the present experiment, the wetted area was approximately half: 6.4\%). When comparing the curve of Eq. (6) obtained in our study with that of previous results from "study MS", it appears that, when $R T$ approaches 1, the two curves tend to converge, but a significant difference still remains, varying between $-0.11 \mathrm{MPa}$ (the smallest difference, when $R T=1$ ) and $-0.45 \mathrm{MPa}$ (when $R T=0.4$ ) (figure $2 b$, table I). By the end of the stress cycles, when $\Psi p$ is below -0.45 the difference for $R T$ stays around 0.35 .

In a third step of our work, the model by Valancogne et al. [22] was applied for the peach orchard under study (drip-irrigated), using $\Psi p_{\text {max }}=-0.17 \mathrm{MPa}($ mean $\Psi p$ prior to irrigation cut, in the stressed plot, as described by the model, see table I). The use of this value for $\Psi p_{\max }$ as a normalisation factor, and of the general equation [Eq. (4)], considering $a=1.28$ [Eq. (2)] and $b=3.43 \Psi p_{\max }+2.16=1.58$ [Eq. (3)], led to $\left[R T=1.28 \mathrm{e}^{1.58 \Psi p}\right]$, Equation (7) (figure 3).

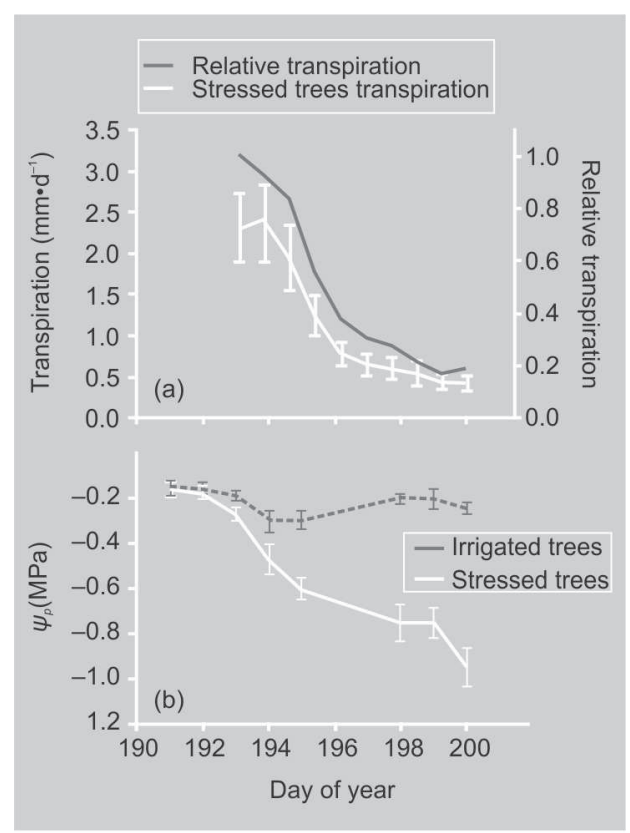

Figure 1.

Evolution of (a) tree transpiration and relative transpiration $(R T)$ and $(\mathrm{b})$ predawn leaf water potential $(\Psi p)$ in well-irrigated and water-stressed plots (peach orchard) during a drying cycle; error bars represent weighted standard deviation in (a) and standard deviation in (b).

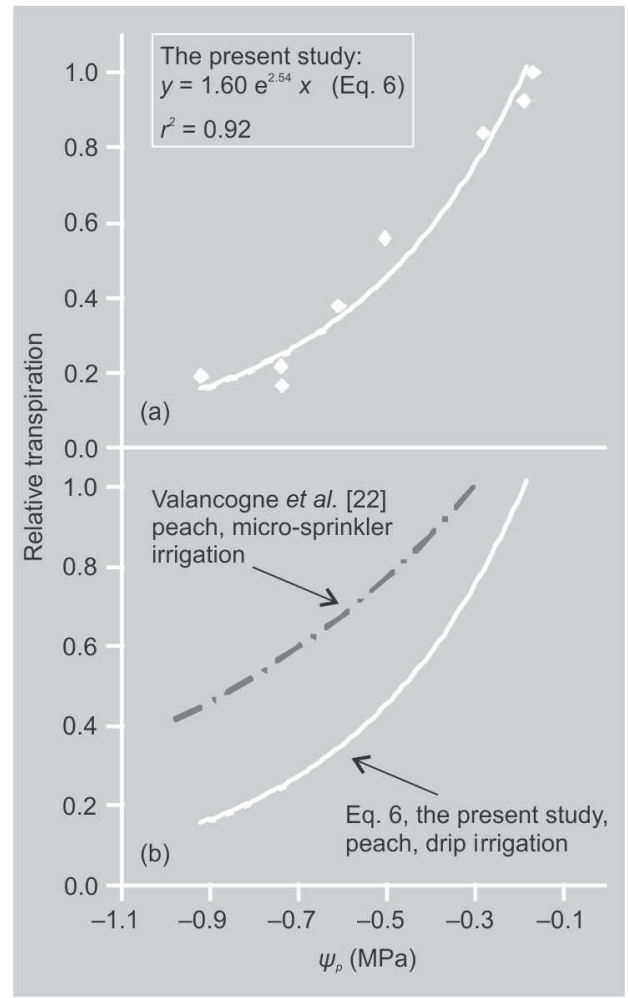

Figure 2.

Experimental relationship between relative transpiration $(R T)$ and predawn leaf water potential ( $\Psi p)$ during a water stress cycle, using a function of the type $R T=a \mathrm{e}^{b \Psi p}$;

(a): Equation (6), the present study; (b): comparison between Equation (6) and a previously obtained relationship for peach orchard, in the same region [22]
The model by Valancogne et al. [22] and the experimental relationship $(R T-\Psi p)$, both for the conditions described here, were then compared. Representation of Eq. (7), that uses $\Psi p_{\text {max }}$ as a normalisation factor, 


\section{Table I.}

Coefficients $a$ and $b$ obtained experimentally in a peach orchard for $\left[R T=a e^{b \Psi p}\right]$ and values of $\Psi p_{\max }$ (mean $\Psi p$ obtained without water stress, prior to irrigation cut) for the present study and that of Valancogne et al. [22].

\begin{tabular}{lccc} 
Experiment & $a$ & $b$ & $\begin{array}{l}\Psi p_{\max } \\
(\mathrm{MPa})\end{array}$ \\
\hline Present study & 1.60 & 2.54 & -0.17 \\
Valancogne et al. [22] & 1.47 & 1.30 & -0.30
\end{tabular}

\section{Figure 3.}

Comparison between modelled relative transpiration $(R T)$ using a general equation and $\Psi p_{\max }$ [22], Equation (7), and $R T$ obtained by regression analysis of field data, Equation (6), under drip irrigation (peach orchard).

Figure 4.

Improved general equation relating predawn leaf water potential $(\Psi p)$ and relative transpiration $(R T)$ during progressive water stress conditions, combining experimental data from the present study and data from Valancogne et al. [22] (peach orchard).
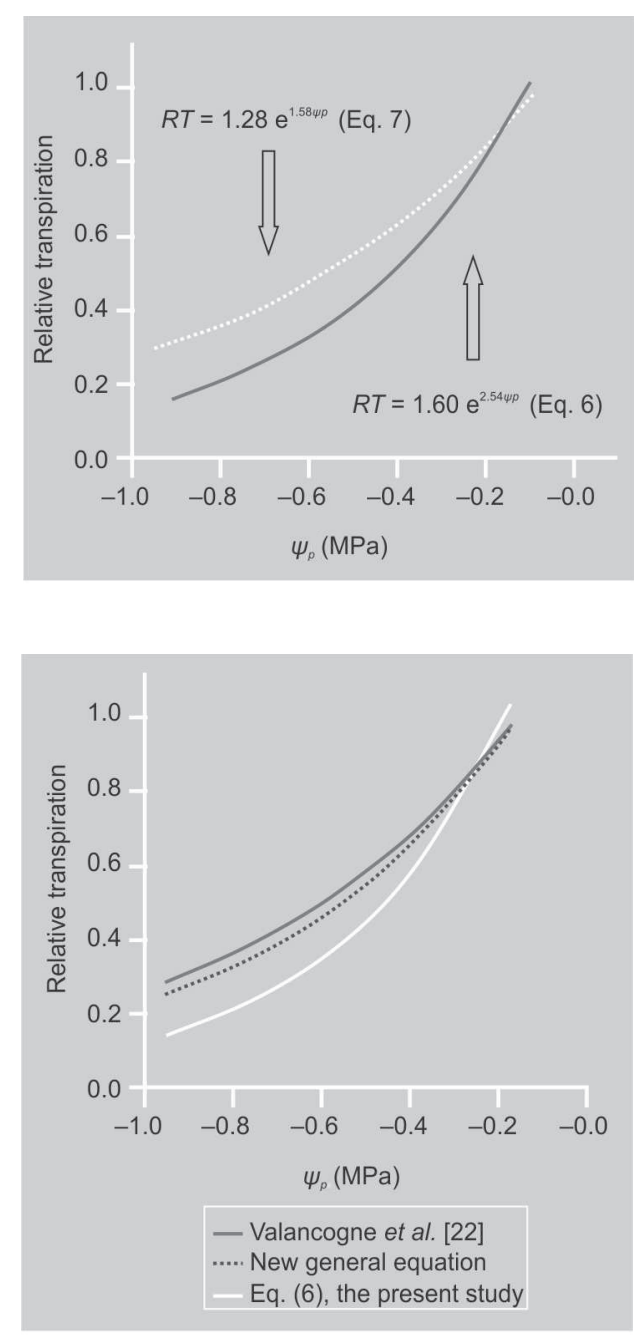

and Eq. (6) obtained experimentally (both for the conditions of this study) shows that the two curves diverge for low values of $\Psi p$ and $R T$ and cross for $R T=0.9$ (figure 3 ).
Finally, data were used to adjust Valancogne et al.'s model [22] and to analyse the behaviour of the model with modified parameters. To integrate new data in the previously established general equation (Eq. 4), it is necessary to relate the parameters $a$ and $b$ obtained experimentally from Eq. (6) $(a=1.60, b=2.54)$, with maximum predawn leaf water potential $\left(\Psi p_{\max }\right.$ ). Eq. (2) and (3), respectively, relate $a$ and $b$ to $\Psi p_{\text {max }}$ of all experiments described by Valancogne et al. [22]. The value obtained experimentally for coefficient $a$ (our study) is above those found by Valancogne et al. [22], where mean $a=1.28$ ( $a$ between 1.20 and 1.50). The value obtained for coefficient $b$ is also higher. Integrating the $a$ and $b$ coefficients found for the orchard under study $(a=1.60$ and $b=2.54)$ and all the $a$ and $b$ coefficients reported by Valancogne et al. [22] in new linear regression models yields:

$$
\begin{gathered}
{\left[a=-0.40 \Psi p_{\max }+1.23\right]} \\
r^{2}=0.09, \text { Equation }(8), \\
{\left[b=4.01 \Psi p_{\max }+2.43\right]} \\
r^{2}=0.66, \text { Equation }(9) .
\end{gathered}
$$

As parameter $a$ was still not well correlated with $\Psi p_{\text {max }}$, a new mean value for $a$ was used (1.32) instead of Eq. (8) or 1.28 [Eq. (7)], and the model with modified parameters became: $\left[R T=1.32 \mathrm{e}^{(4.01} \Psi\right.$ max + 2.43) $\Psi$ ], Equation (10) (figure 4, new general equation).

\section{Discussion}

\subsection{The $R T-\Psi p$ relationship for the orchard studied and comparison of the $R T$ - $\Psi p$ relationship under different irrigation systems}

A good correlation was found between $R T$ and $\Psi p\left(r^{2}=0.92\right)$; the $a$ and $b$ parameters determined for the experiment were $a=1.60$ and $b=2.54$ [Eq. (6)] (figure 2a). As for other fruit tree species [22], the function type of Eq. (1) adequately described the experimental relationship between the two variables. The use of a non-linear fitting is 


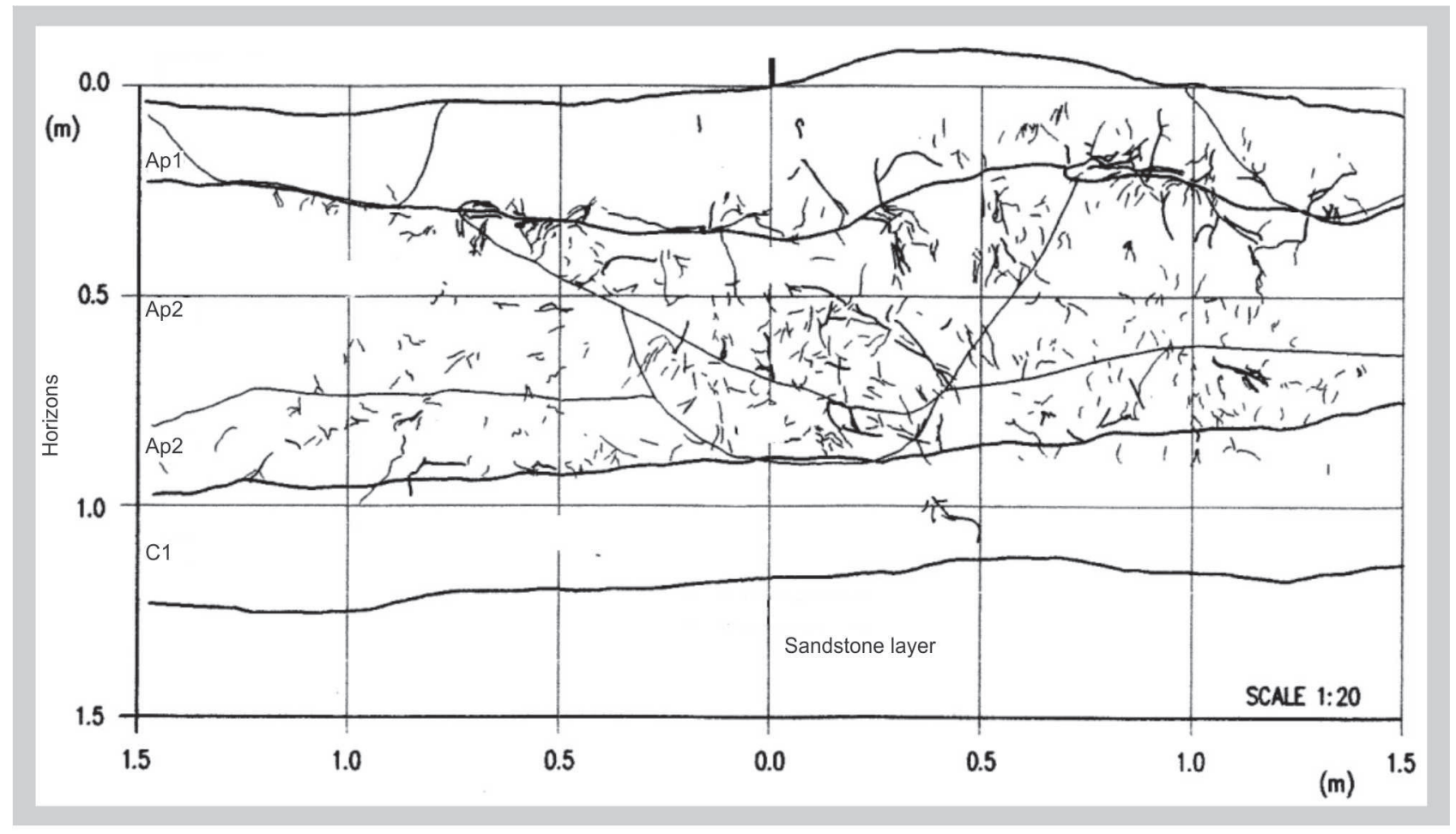

also supported by the fact that unsaturated hydraulic conductivity (in Darcy's law) exponentially decreases as soil dries out. Therefore, a decreasing slope for $R T$ is expected when $\Psi p$ is lower.

Comparing the $R T-\Psi p$ relationship obtained [Eq. (6), drip irrigation] and that for a similar orchard with a different irrigation system (micro-sprinkler, "study MS", figure $2 b$, table I) shows that, although they provide close results when $R T$ is around 1, $R T$ is very different for lower values of $\Psi p$. The reason for the lower values of $R T$ in our study might be a result of a lack of adaptation to water stress, even a moderate one, resulting from the high frequency of irrigation (daily) and its localised character [one emitter on the north side of the tree and another on the south side, with a small (6.4\%) wetted area], determining the lower volume of the root system, in contrast to the "study MS". The latter study indicates a time interval between irrigation events of three or more days, regularly inducing moderate water stress. Further, the wide spatial distribution of the micro-sprinklers ${ }^{1}$ induced a less localised root development. This longer development implies a larger volume explored by each root fraction, with wider root distribution and water pathways in the soil, as observed by other authors, for example, in olive trees [33].

Differences in soil profile can provide further understanding. In this study, the soil profile included a coarse sand layer, approximately at $1.2 \mathrm{~m}$ depth, with large discontinuous macropores. Given the sandy nature of the soil, water tends to descend quickly until this layer. Afterwards, due to pore discontinuity, it acts as an obstacle and induces a pronounced lateral flow [28] so that roots explore mainly the soil volume above.

In "study MS", sandstone could be found in the soil profile below $1.2 \mathrm{~m}$ deep (figure 5). This material allows high water percolation with little retention. Also, the macropores (10\% to $15 \%$ ) provide paths for

1 Micro-sprinklers distributed on the row, with $4 \mathrm{~m}$ between them and $1 \mathrm{~m}$ away from the nearest tree.
Figure 5.

Peach tree vertical root distribution described by the interception of a plan registered on a plastic film. 
Figure 6.

Peach tree horizontal root distribution described by the interception of a plan registered on a plastic film. Comparison of root map of four horizontal soil layers (study with micro-sprinkler irrigation = "study MS").

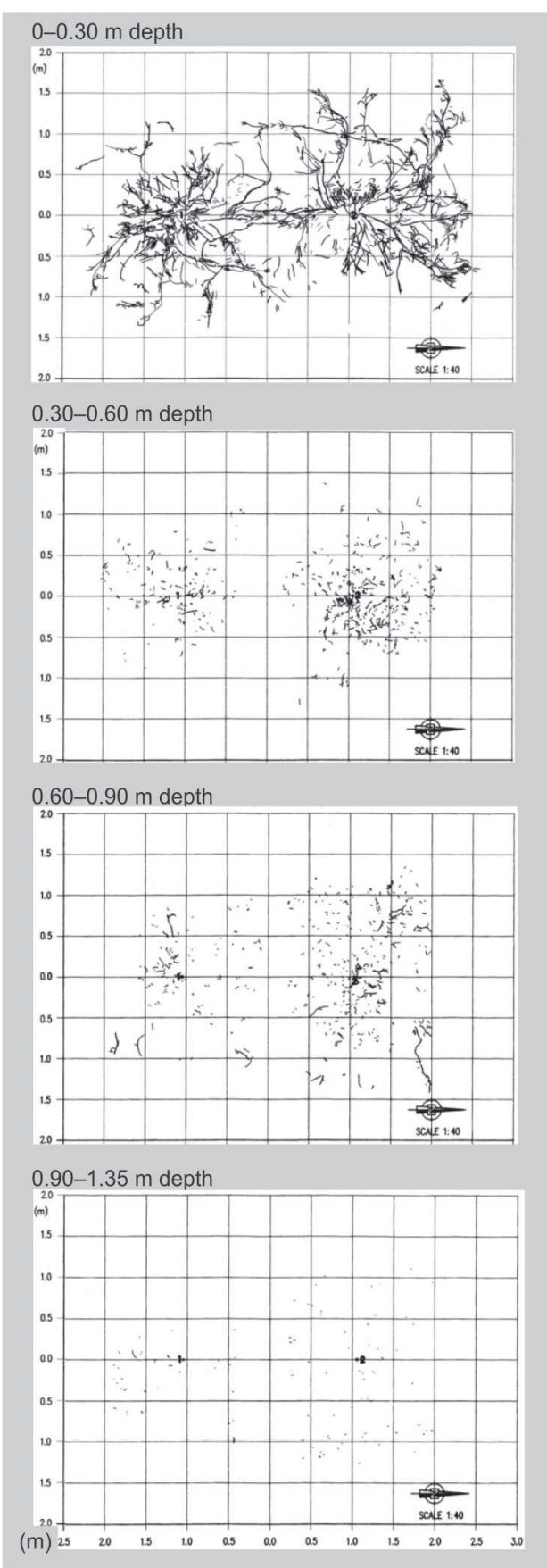

the penetration of roots to a lower depth $(1.35 \mathrm{~m})$.

Therefore, in our study, given the narrower wet bulb resulting from drip irrigation, roots were more concentrated, while, in "study MS", water accessed deeper layers and roots explored a larger soil volume ( $f i g$ ure 0 ). The differences in root development observed between the two experiments were induced by the irrigation method that, due to differences in irrigation frequency, and consequently irrigation depths, in their turn, influenced root bulk volume. The differences found for the relationship $R T$ versus $\Psi p$ can therefore result from the two distinct types of irrigation, concerning temporal and spatial water distribution. This seems to be in agreement with the expected behaviour, considering the implications of the above in water uptake rates, controlled by hydraulic conductivity and average length of water pathways [34, 35].

\subsection{Testing a general $R T-\Psi p$ model}

Given these results (differences between Eq. (6) and Eq. (7), figure 3), we further analysed the impact of using the model [Eq. (4)]. Under deficit irrigation practices, $R T$ of deciduous fruit trees should not go beyond a minimum value of 0.6 , in most cases [36, 37], to avoid yield and quality losses. For peach, a minimum $R T$ successfully tested value is around 0.7 (moderate stress) $[15,38,39]$. The value of $\Psi p$ that yields $R T$ equal to 0.7 in the experimental equation [Eq. (6)] is $-0.33 \mathrm{MPa}$. Using $\Psi p=-0.33 \mathrm{MPa}$ in Eq. (7) leads to $R T=0.76$. Therefore, when lowering $R T$ to 0.7 , the difference between $R T$ estimates using the equation obtained experimentally and the general equation is 0.06. As $R T=0.7$ can be considered a maximum likely reduction, the error is below 9\% $(=0.06 / 0.7)$. Consequently, the general equation proposed by Valancogne et al. [22] was shown to be useful for estimating $R T$. Similarly, the use of this general equation proves to be appropriate for drip irrigation conditions, even if established for other irrigation systems and possibly irrigation intervals inducing different root density patterns. This derives from establishing a working interval for $R T$ values, between 0.7 and 1 , as the dissimilarities among systems concerning irrigation method, irrigation depths and lithology do not induce large differences in that range. 


\subsection{Analysing the general RT- $\Psi p$ model with modified parameters}

Equation (10) is a new general equation including information from this study. It displayed $R T$ values 0.1 below experimental values [Eq. (6)] and 0.02 below those provided by the previous general equation (Eq. (4), [22]) for $R T=0.7$. Therefore, for $R T$ around 0.7 , both general equations can be used to obtain $R T$ estimates with an $R T$ error below 0.1 (figure 4). For lower $R T$, a larger error is introduced and the model should be used with caution as it does not describe well the impact of differences in root density on transpiration rates when the soil becomes drier.

Although studies on this topic are rare, other authors have presented results on $R T$ and $\Psi p$. From results presented by Ortuno et al., for potted lemon trees, it is possible to build a relationship of the type $R T=a \mathrm{e}^{b \Psi p} \quad(a=1.25$ and $b=0.32$, $r^{2}=0.87$ ) [40]. Nevertheless, $\Psi p$ values presented by these authors for well-irrigated plants ( $\Psi$ p around $-0.75 \mathrm{MPa}$ ) are outside of the expected range [22], including in citrus species [41, 42], being much lower than expected. Therefore, the model from Valancogne et al. [22] was not tested for these data.

Maotani and Machida have used weighing lysimeters and potted satsuma mandarin (Citrus unshiu Marc.) trees to relate $R T$ and $\Psi p$ [43]. From their data, it is possible to observe that $R T$ was highly correlated with $\Psi p\left(r^{2}=0.99, a=1.24\right.$ and $\left.b=0.60\right)$. Comparing this experimental relationship with the model application [Eq. (4)] indicates a progressive deviation in $R T$ predicted by both ways, as $\Psi p$ decreases, the model estimates being much lower, and application of the model would lead to large errors. This might be partially a result of having lower ET rates (around $2 \mathrm{~mm} \cdot \mathrm{d}^{-1}$ ) when compared with field situations (e.g., [44], close to $3 \mathrm{~mm} \cdot \mathrm{d}^{-1}$ ), as $E T$ rates are known to affect this relationship significantly [45].

The results from Maotani and Machida [43] and Ortuno et al. [40] were not included in the reformulation of Valancogne et al.'s model [22], mainly because, in those experiments, plants were potted, which influences the way $E T$ rates relate to available water and, specially, providing non-comparable conditions for the purpose of this study, given the high root density, in relation to field conditions.

\section{Conclusions}

For the peach orchard under study, relative transpiration ( $R T$, below unity) was shown to be highly related to variations in predawn leaf water potential ( $\Psi p$ ) during progressive water stress conditions. The experimental relationship established, under daily drip irrigation, largely differed from a previous one obtained in a peach orchard in the same region, with a similar soil, yet with microsprinkler irrigation every three or more days. This indicates that irrigation method and frequency are key factors, inducing spatial and temporal variability in water distribution, which affects root density and volume and therefore the $R T-\Psi p$ relationship. This problem was solved by the use of a previously established method [22] to obtain parameters for the relationship to estimate $R T$ from $\Psi p$. In fact, this approach proved to be valid here, under moderate stress conditions and for practical uses. This general relationship ( $\Psi p$ versus $R T$ ) allows scheduling irrigation using only $\Psi p$ measurements to estimate $R T$. This is valid even under an irrigation system (drip) different from those used where the relationship was originally obtained (trickle, sprinkler and micro-sprinkler).

These results can contribute to improving tools for irrigation scheduling of peach orchards under water stress conditions, allowing the use of deficit irrigation, saving water without reducing yield.

\section{Acknowledgements}

This work received support from: 1) Project FAIR-CT 95-0030, EU; 2) the Foundation for Science and Technology, FCT, Portugal, and the European Social Fund (Ph.D. and Post-doc fellowships, first author); 3) the ICCTI-Institute of International Science and Technology Cooperation, Portugal/French 
Embassy Protocol. The authors thank Dr. Charles Valancogne for support with the heat balance method and Dr. Sadanori Sase for Japanese translations.

\section{References}

[1] Goldhamer D.A., Irrigation scheduling with plant indicators: measurement, in: Trimble S.W., Stewart B.A., Howell T.A. (Eds.), Encyclopaedia of Water Science, Marcel Dekker, N.Y., U.S.A., 2003.

[2] Jones H.G., Irrigation scheduling: advantages and pitfalls of plant-based methods, $\mathrm{J}$. Exp. Bot. 55 (2004) 2427-2436.

[3] Geerts,S., Raes D., Deficit irrigation as an on-farm strategy to maximise crop water productivity in dry areas, Agric. Water Manag. 96 (2009) 1275-1284.

[4] Durán Zuazo V.H., Rodríguez Pleguezuelo C.R., Tarifa D.F., Impact of sustained-deficit irrigation on tree growth, mineral nutrition, fruit yield and quality of mango in Spain, Fruits 66 (2011) 257-268.

[5] Beniken L., Beqqali M., Dahan R., Benkirane R., Omari F.E., Benazouz A., Hamid Benyahia H., Gaboun F., Évaluation de la résistance de dix porte-greffes d'agrumes résistants à la tristeza vis-à-vis du déficit hydrique, Fruits 66 (2011) 373-384.

[6] Itier B., Maraux F., Ruelle P., Deumier J.M., Applicability and limitations of irrigation scheduling methods and techniques, in: Smith M., Pereira L.S., Berengena J., Itier B., Goussard J., Ragab R., Tollefson L., van Hofwegen P. (Eds.), Irrigation scheduling: from theory to practice, FAO, Rome, Italy, 1996.

[7] Katerji N., Les indicateurs de l'état hydrique de la plante, in: Riou C., Bonhomme R., Chassin P., Neveu A., Papy F. (Eds.), L'eau dans I'espace rural, INRA, Paris, Fr., 1997.

[8] Jones H.G., Monitoring plant and soil water status: established and novel methods revisited and their relevance to studies of drought tolerance, J. Exp. Bot. 58 (2007) 119-130.

[9] Kriston-Vizi J., Umeda M., Miyamoto K., Assessment of the water status of mandarin and peach canopies using visible multispectral imagery, Biosyst. Eng. 100 (2008) 338-345.

[10] Ameglio T., Archer P., Cohen M., Valancogne C., Daudet F.A., Dayau S., Cruiziat P., Significance and limits in the use of predawn leaf water potential for tree irrigation, Plant Soil 207 (1999) 155-167.
[11] Williams L.E., Araujo F.J., Correlations among predawn leaf, midday leaf, and midday stem water potential and their correlations with other measures of soil and plant water status in Vitis vinifera, J. Am. Soc. Hortic. Sci. 127 (2002) 448-454.

[12] Allen R.G., Pereira L.S., Raes D., Smith M., Crop evapotranspiration guidelines for computing crop water requirements, FAO Irrigation and Drainage Paper 56, Rome, Italy, 1998.

[13] Itier B., Ferreira M.I., Katerji N., Evolution journalière du coefficient de sècheresse entre deux irrigations sur tomate, in: di Castri F., Floret Ch., Rambal S., Roy J., Proc. 5th Int. Conf. Mediterranean Ecosystems, IUBS, Paris, Fr., 1988, pp. 191-196.

[14] Itier B., Katerji N., Ferreira M.I., Flura D., Relative evapotranspiration in relation to soil water and predawn leaf water potential: Application to a tomato crop, Acta Hortic. 278 (1990) 101-112.

[15] Ferreira M.I., Valancogne C., Experimental study of a stress coefficient: application on a simple model for irrigation scheduling and daily evapotranspiration estimation, in: Farkas I. (Ed.), Proc. 2nd Int. Symp. Mathematical modeling and simulation in agricultural and bio-industries, Bp., Hung., 1997.

[16] Katerji N., Itier B., Ferreira I., A study of several indicators of the water status of a tomato crop in a semi-arid region, Agronomie 8 (1988) 425-433.

[17] Goldhamer D.A., Viveros M., Salinas M., Regulated deficit irrigation in almonds: effects of variations in applied water and stress timing on yield and yield components, Irrig. Sci., 24 (2006) 101-114.

[18] Intrigliolo D.S., Castel J.R., Performance of various water stress indicators for prediction of fruit size response to deficit irrigation in plum, Agric. Water Manag. 83 (2006) 173-180.

[19] Bond B.J., Kavanagh K.L., Stomatal behavior of four woody species in relation to leafspecific hydraulic conductance and threshold water potential, Tree Physiol. 19 (1999) 503-510.

[20] Tuzet A., Perrier A., Leuning R., A coupled model of stomatal conductance, photosynthesis and transpiration, Plant Cell Environ. 26 (2003) 1097-1116.

[21] Ferreira M.I., Pacheco C.A., Valancogne C., Michaelsen J., Ameglio T., Daudet F.A., Evapotranspiration, water stress indicators and soil water balance in a Prunus persica orchard, in central Portugal, Acta Hortic. 449 (1997) 379-384. 
[22] Valancogne C., Dayau S., Ameglio T., Archer P., Daudet F.A., Gama M.I.F., Cohen M., Relations between relative transpiration and predawn leaf water potential in different fruit tree species, Acta Hortic. 449 (1997) 423-429.

[23] Ferreira-Gama M.I.F.R., Evapotranspiração real. Estudo realizado na cultura do tomate em região de clima mediterrânico, Univ. Téc. Lisboa, Inst. Sup. Agron., Thesis, Lisb., Port., 1987, 168 p.

[24] Silva R.M., Desenvolvimento de um sistema inteligente de determinação das necessidades hídricas para cultura de lenhosas anisotrópicas, Tech. Univ. Lisb., Inst. Sup. Agron., Thesis, Lisb., Port., 2009, 267 p.

[25] Fernandez J.E., Moreno F., Cabrera F., Arrue J.L., Martinaranda J., Drip irrigation, soil characteristics and the root distribution and root activity of olive trees, Plant Soil 133 (1991) 239-251.

[26] Lee R., Forest microclimatology, Columbia Univ. Press, N.Y., U.S.A., 1978.

[27] Deckers J.A., Nachtergaele F.O., Spaargaren O.C., World reference base for soil resources: Introduction, FAO, ISRIC Acco, Leuven, Belg., 1998.

[28] Hagrey S.A. al, Michaelsen J., Hydrogeophysical soil study at a drip irrigated orchard, Portugal, Eur. J. Environ. Eng. Geophys. Soc. 7 (2002) 75-93.

[29] Valancogne C., Nasr Z., A heat-balance method for measuring the sap flow in small trees, Agronomie 9 (1989) 609-617.

[30] Valancogne C., Nasr Z., A heat balance method for measuring sap flow in small trees, in: Borghetti J.G.M., Raschi A. (Eds.), Water transport in plants under climatic stress, Camb. Univ. Press, U.K., 1993.

[31] Sakuratani T., A heat balance method for measuring water flux in the stem of intact plants, J. Agric. Meteorol. 37 (1981) 9-18.

[32] Valancogne C., Dayau S., Pieri P., Ferreira M.I., Silvestre J., Angelocci L.R., Influence of orchard and vineyard characteristics on maximal plant transpiration, Acta Hortic. 537 (2000) 61-68.

[33] Santos F.L., Valverde P.C., Ramos A.F., Reis J.L., Castanheira N.L., Water use and response of a dry-farmed olive orchard recently converted to irrigation, Biosyst. Eng. 98 (2007) 102-114

[34] Sperry J.S., Adler F.R., Campbell G.S., Comstock J.P., Limitation of plant water use by rhizosphere and xylem conductance: results from a model, Plant Cell Environ. 21 (1998) 347-359.

[35] Roberts J., The influence of physical and physiological characteristics of vegetation on their hydrological response, Hydrol. Process. 14 (2000) 2885-2901.

[36] Costa J.M., Ortuno M.F., Chaves M.M., Deficit irrigation as a strategy to save water: Physiology and potential application to horticulture, J. Integr. Plant Biol. 49 (2007) 1421-1434.

[37] Fereres E., Soriano M.A., Deficit irrigation for reducing agricultural water use, J. Exp. Bot. 58 (2007) 147-159.

[38] Girona J., Gelly M., Mata M., Arbones A., Rufat J., Marsal J., Peach tree response to single and combined deficit irrigation regimes in deep soils, Agric. Water Manag. 72 (2005) 97-108.

[39] Guangyong L., Xingfa H., Xiaowei W., Water use of drip irrigated peach trees under full irrigation and regulated deficit irrigation, in: Proc. 6th Int. Micro-irrig. Cong. Micro-irrigation Technology for Developing Agriculture, S. Afr., 2000, pp. 1-6.

[40] Ortuno M.F., Alarcon J.J., Nicolas E., Torrecillas A., Sap flow and trunk diameter fluctuations of young lemon trees under water stress and rewatering, Environ. Exp. Bot. 54 (2005) 155-162.

[41] Ruiz-Sanchez M.C., Domingo R., Save R., Biel C., Torrecillas A., Effects of water stress and rewatering on leaf water relations of lemon plants, Biol. Plant. 39 (1997) 623-631.

[42] Gonzalez-Altozano P., Castel J.R., Effects of regulated deficit irrigation on 'Clementina de Nules' citrus trees growth, yield and fruit quality, Acta Hortic. 537 (2000) 749-758.

[43] Maotani T., Machida Y., Changes in transpiration rate, leaf diffusion resistance and leaf water potential for satsuma mandarin (Citrus unshiu Marc.) trees during prolonged water stress and subsequent recovery, J. Agric. Meteorol. 32 (1977) 203-209.

[44] Paço T.A., Conceição N., Ferreira M.I., Measurements and estimates of peach orchard evapotranspiration in Mediterranean conditions, Acta Hortic. 664 (2004) 505-512.

[45] Denmead O., Shaw R., Availability of soil water to plants as affected by soil moisture content and meteorological conditions, Agron. J. 54 (1962) 385-390. 


\section{Planificación de la irrigación de un vergel de melocotoneros en condiciones de estrés hídrico: utilización de la transpiración relativa y del potencial hídrico de base foliar.}

Resumen - Introducción. Los indicadores del estrés hídrico vegetal se han vuelto esenciales para llevar a cabo estrategias de irrigación en caso de déficit y de ahorro de agua. En este caso, la evapotranspiración (ET) es inferior a su valor máximo para el cultivo y para la fase $(E T C)$, y se aplica un coeficiente de tensión (KS) para obtener el valor real de ET (ETr). El potencial hídrico de base foliar $(\Psi p)$ puede estar unido a la transpiración relativa $(R T)$, relación entre la transpiración de una parcela estresada $(T)$ y la transpiración de una parcela bien irrigada (Tm). La estimación de $R T$ a partir de $\Psi p$ permite calcular la ETr para determinar las dosis de irrigación, si se aplica una irrigación en condiciones de déficit, dado que $R T$ corresponde aproximadamente a $K s$. Material y métodos. $R T$ y $\Psi p$ se midieron con el fin de establecer una relación para estimar $R T$ bajo un estrés hídrico moderado, para programar la irrigación en un vergel de melocotoneros en el sur de Portugal. Se calculó $R T$ a partir de la medida del flujo de savia (balance térmico) en dos parcelas, una bien irrigada (cantidades de irrigación diaria por goteo calculadas para $T m$ ) y otra temporalmente no irrigada. Resultados y discusión. Se observó una fuerte correlación entre $R T$ y $\Psi p$, lo que permitió estimar $R T$ en condiciones estudiadas. Se encontraron importantes diferencias en cuanto a la relación $R T$ $\Psi p$ obtenida para otro vergel de melocotoneros de la misma región, que dispusiera de condiciones pedológicas similares, para $\Psi p$ comprendido entre -0,11 MPa y $-0,45 \mathrm{MPa}$. Los resultados sugieren que dichas diferencias resultaron de diferentes sistemas de irrigación empleados: goteo o microaspersores, ya que éstos determinan la distribución espacial y temporal del agua en el suelo, y, por lo tanto, la diferente geometría del sistema radicular. Se testeó una ecuación anteriormente propuesta para estimar $R T$ a partir $\Psi p$, con una forma general para las diferentes especies de árboles frutales, y resulta suficiente con ciertos límites: hasta $R T=0,7$, el error resultó ser inferior al $9 \%$. El valor de aceptabilidad $R T=0,7$ se consideró como un mínimo, ya que se testeó exitosamente durante la utilización de irrigación en condiciones de déficit para los vergeles de melocotoneros.

Portugal / Prunus persica / estrés hídrico / déficit de humedad en el suelo / indicadores / plantas deciduas / árboles frutales / necesidades de agua / riego a la demanda 